\title{
Tonsillektomia z zastosowaniem skalpela harmonicznego - doświadczenie własne i przegląd literatury
}

\section{Harmonic scalpel tonsillectomy - personal experience and review of literature}

\author{
Marian Kurzyński, Joanna Szaleniec, Jacek Składzień \\ Katedra i Klinika Otolaryngologii UJ CM \\ Kierownik: prof. dr hab. J. Składzień
}

\begin{abstract}
Summary
Introduction. The harmonic scalpel has been used in tonsil surgery for several years. The comparison of harmonic scalpel tonsillectomy with other tonsillectomy techniques has been the subject of many studies. The research results proved to be contradictory, particularly concerning postoperative complications and complaints. Most authors observed reduced intraoperative bleeding during harmonic scalpel tonsillectomy. Objective. Analysis of harmonic scalpel tonsillectomy results and review of literature. Material and methods. The harmonic scalpel was used for 71 tonsillectomies in the Department of Otolaryngology UJ CM between 2002-2007. The surgical procedure and postoperative results were analyzed retrospectively and compared with other tonsillectomy techniques. Results. The harmonic scalpel provided sufficient intraoperative hemostasis in $67 \%$ of cases. $33 \%$ of patients required electrocautery, vessel ligation in the operation field or suturing of the marginal tissue to control bleeding. Postoperative hemorrhage requiring surgical intervention occurred in 3 patients. No other severe postoperative complications were observed in either group. Conclusions. Harmonic scalpel tonsillectomy is an effective and safe alternative technique in tonsil surgery. In some cases however other hemostasis techniques may be necessary to control intense bleeding.
\end{abstract}

Ha sła indeks owe: tonsillektomia, powikłania pooperacyjne, skalpel harmoniczny

Ke y w or d s : tonsillectomy, postoperative complications, hemostatic techniques, postoperative hemorrage, harmonic scalpel

Otolaryngol Pol 2008; LXII (5): 561-566 @ 2008 by Polskie Towarzystwo Otorynolaryngologów - Chirurgów Głowy i Szyi

\section{WSTĘP}

Metodyka usuwania migdałków podniebiennych ewoluuje i jest doskonalona od ponad 2000 lat. Od czasu przeprowadzenia pierwszych tonsillektomii polegających na palpacyjnym wypreparowaniu migdałków z loży, w tego rodzaju zabiegach zastosowanie znalazło wiele nowych narzędzi i technik [1, 2]. Od kilku lat w chirurgii migdałków podniebiennych zastosowanie znajduje skalpel harmoniczny, wcześniej wykorzystywany z powodzeniem między innymi w chirurgii laparoskopowej, torakochirurgii, chirurgii gastroenterologicznej czy ginekologicznej. Zasada jego działania opiera się na wykorzystaniu wibracji o wysokiej częstotliwości do przecinania tkanek z ich równoczesną koagulacją. Temperatura generowana przez elektrokoagulację osiąga $400^{\circ} \mathrm{C}$, co skutkuje wysuszaniem i zwęgleniem tkanki, natomiast skalpel harmoniczny generuje temperatury $50-100^{\circ} \mathrm{C}$, które są wystarczające do uzyskania efektu denaturacji białka, nie powodują jednak znacznej martwicy otoczenia [2-4]. Tonsillektomia z zastosowaniem noża harmonicznego powinna być procedurą minimalnie inwazyjną, a także bezpieczną. Dotychczas przeprowadzone badania nie potwierdzają tych oczekiwań w sposób jednoznaczny [3-24].

Celem pracy była ocena przebiegu oraz wyników tonsillektomii z użyciem skalpela harmonicznego w materiale Katedry i Kliniki Otolaryngologii UJ CM.

\section{MATERIAŁ I METODY}

W Klinice Otolaryngologii UJ CM skalpel harmoniczny stosuje się w zabiegach tonsillektomii od 2002 roku. W latach 2002-2007 operowano z wykorzystaniem

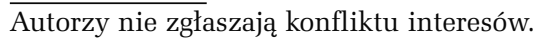


tej techniki 71 pacjentów w wieku 4-75 lat (średnia wieku 36 lat). Grupa badana obejmowała 22 kobiety i 49 mężczyzn. Większość pacjentów (65) stanowili dorośli. Wskazania do zabiegu obejmowały nawracające ostre zapalenia migdałków podniebiennych, przebyte ropnie okołomigdałkowe, stany zapalne stawów, zespół obturacyjnego bezdechu sennego, dolegliwości bólowe spowodowane przez przedłużony wyrostek rylcowaty. U 7 pacjentów z zespołem obturacyjnego bezdechu sennego poza tonsillektomią wykonano dodatkowo uwulopalatofaryngoplastykę z użyciem skalpela harmonicznego, u 5 pacjentów w sposób typowy usunięto przedłużony wyrostek rylcowaty, u 1 dziecka wykonano dodatkowo klasyczną adenotomię (bez zastosowania noża harmonicznego przy usuwaniu migdałka gardłowego). Oceniono grupę pacjentów operowanych z zastosowaniem skalpela harmonicznego przez jednego tylko operatora i porównano ją z grupą kontrolną, do której włączono wszystkich chorych hospitalizowanych w Klinice Otolaryngologii UJ CM w roku 2007, u których wykonano tonsillektomię techniką klasyczną. Grupę tę stanowiło 95 pacjentów w wieku 3-78 lat (średnia wieku 27 lat), w tym 53 kobiety i 42 mężczyzn, 76 dorosłych i 19 dzieci. Wskazania do zabiegu w tej grupie obejmowały nawracające infekcje migdałków podniebiennych, przebyte ropnie okołomigdałkowe, zespół bezdechu sennego, a także nefrologiczne, okulistyczne i reumatologiczne powikłania przewlekłego zapalenia migdałków (kłębuszkowe zapalenie nerek, zapalenie tęczówki, zapalenie stawów) oraz usuwanie migdałka jako poszerzony wycinek przy podejrzeniu choroby nowotworowej tego narządu.

Analizując dokumentację medyczną porównano przebieg zabiegu oraz wyniki leczenia chorych operowanych z zastosowaniem skalpela harmonicznego i pacjentów operowanych techniką klasyczną. Celem oceny statystycznej chorych podzielono na 2 grupy. Grupa 1 obejmowała chorych, u których koagulacja krwawiących naczyń za pomocą skalpela harmonicznego okazała się niedostatecznie wydolna i konieczne było zastosowanie dodatkowych metod (elektrokoagulacja, zszycie łuków podniebiennych, podwiązanie naczyń w niszy po migdałkach). Do grupy 2. zakwalifikowano tych pacjentów, u których hemostazę uzyskano, używając wyłącznie skalpela harmonicznego. Z grupy 2. wyodrębniono dodatkowo podgrupę 3., w której operację opisano jako „praktycznie bezkrwawą”. Najwyższą średnią wieku stwierdzono w grupie 1. (41,3 lat), niższą w grupie 2. (33,6 lat), najniższą natomiast w podgrupie 3. (23,5 lat). W grupie wymagającej dodatkowej hemostazy (grupa 1) nie znalazło się żadne z 6 operowanych za pomocą skalpela harmonicznego dzieci. Badanie normalności rozkładu we wszystkich trzech grupach przeprowadzono stosując testy Kołmogorowa-Smirnowa, Lillieforsa i Shapiro-Wilka. Do sprawdzenia jednorodności wariancji zastosowano test Fishera. W celu oceny istotności statystycznej różnicy wieku pomiędzy poszczególnymi grupami zastosowano test $\mathrm{t}$ dla zmiennych niepowiązanych.

\section{WYNIKI}

Wszyscy chorzy byli operowani w znieczuleniu ogólnym, u większości rura intubacyjna była wprowadzana przez nos do tchawicy. Nikt z operowanych nie umarł, nikt nie miał ubytków w funkcji nerwów ruchowych i czuciowych, w tym zaburzeń smakowych języka. Nikt z chorych nie miał powikłań infekcyjnych po operacji zarówno miejscowych, jak i systemowych.

\section{Hemostaza śródoperacyjna}

Pełną hemostazę wyłącznie za pomocą skalpela harmonicznego uzyskano śródoperacyjnie u 67\% chorych, w tym u 11\% chorych operacja przeprowadzona została w sposób praktycznie bezkrwawy. 17\% operowanych wymagało dodatkowego zastosowania elektrokoagulacji, 4\% podwiązania krwawiących naczyń, 8\% zeszycia łuków podniebiennych. W 4\% przypadków ze względu na trudne warunki i nasilone krwawienie konieczna była zmiana techniki operacyjnej na klasyczną.

Analiza zastosowanych w trakcie zabiegów metod hemostazy wykazała, że skuteczność opanowania krwawienia śródoperacyjnego z użyciem skalpela harmonicznego silnie koreluje $\mathrm{z}$ wiekiem pacjentów. Opracowanie statystyczne uzyskanych wyników potwierdziło, że istnieje istotna statystycznie różnica wieku między grupą chorych, u których skalpel harmoniczny stanowił jedyne narzędzie uzyskania hemostazy, a chorymi, którzy wymagali dodatkowego zastosowania elektrokoagulacji, podwiązania naczyń lub zeszycia łuków podniebiennych (porównanie grup 1. i 2., p < 0,05). Jeszcze wyraźniej zaznaczona jest różnica wieku między chorymi wymagającymi dodatkowych metod hemostazy z powodu nasilonego krwawienia a pacjentami, u których krwawienie było znikome (porównanie grup 1. i 3., p < 0,01). Uzyskane wyniki sugerują, że skalpel harmoniczny można uznać za skuteczne narzędzie zmniejszające krwawienie śródoperacyjne przede wszystkim u osób młodych (ryc. 1, 2).

\section{Powikłania pooperacyjne}

Krwawienia wtórne wymagające lokalnej interwencji chirurgicznej wystąpiły w badanej grupie u 3 chorych (4\%). W przypadku krwawień wtórnych nie stwierdzono korelacji z wiekiem pacjentów ani żad- 


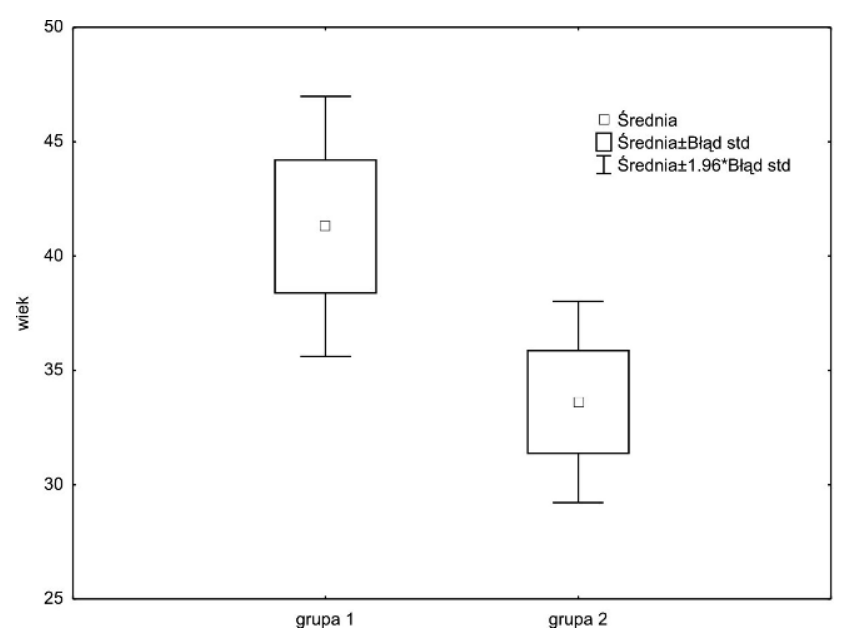

Ryc. 1. Porównanie wieku pacjentów, u których zastosowano dodatkowe metody hemostazy (grupa 1.), i pacjentów, u których opanowano krwawienie wyłącznie za pomocą skalpela harmonicznego (grupa 2.)

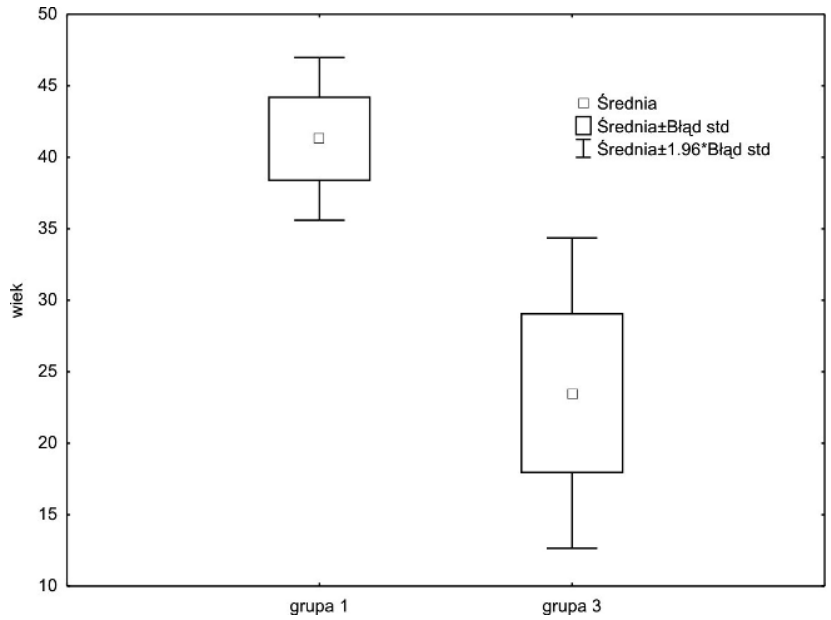

Ryc. 2. Porównanie wieku pacjentów, u których zastosowano dodatkowe metody hemostazy (grupa 1.), i pacjentów, u których krwawienie śródoperacyjne było szczególnie znikome (grupa 3.)

Tabela I. Pacjenci operowani z zastosowaniem skalpela harmonicznego, u których wystąpiły krwawienia wtórne po tonsillektomii z zastosowaniem skalpela harmonicznego

\begin{tabular}{l|l|l|l}
\hline Wiek & Płeć & Czas wystąpienia krwawienia po zabiegu & Metody uzyskania hemostazy w trakcie tonsillektomii \\
\hline 17 & Mężczyzna & 1 doba & Po jednym szwie zblżającym przy podniebieniu miękkim obustronnie \\
\hline 40 & Mężczyzna & 3 doba & Wyłącznie skalpel harmoniczny \\
\hline 57 & Kobieta & 8 doba & Wyłącznie skalpel hamoniczny \\
\hline
\end{tabular}

nych określonych czynników ryzyka wystąpienia krwawienia pooperacyjnego. W grupie chorych operowanych techniką klasyczną krwawienie pooperacyjne wymagające zszycia łuków podniebiennych wystąpiło u 1 chorej (1\%). W grupie pacjentów operowanych z zastosowaniem skalpela harmonicznego, analogicznie jak w przypadku pacjentów operowanych techniką klasyczną, nie zanotowano innych powikłań odległych (tab. I).

\section{Czas trwania zabiegu}

Czas trwania tonsillektomii oszacowano jako czas od momentu intubacji do ekstubacji, przy czym pod uwagę wzięto jedynie dokumentację tych chorych, u których nie wykonywano żadnych dodatkowych procedur poza usunięciem migdałków podniebiennych. Czas trwania zabiegu z zastosowaniem skalpela harmonicznego wynosił od 25 do 65 min, średnio 45 min, natomiast w przypadku techniki klasycznej 25 do $140 \mathrm{~min}$, średnio $52 \mathrm{~min}$. Różnica ta nie jest statystycznie istotna (test $t$-Studenta dla prób niezależnych, $\mathrm{p}=0,2$ ).

\section{Krzywa uczenia się stosowania}

\section{noża harmonicznego przez operatora}

Celem wykreślenia krzywej uczenia się techniki tonsillektomii z zastosowaniem skalpela harmonicznego porównano w kolejnych latach procent zabiegów, w których opanowano krwawienie wyłącznie z użyciem skalpela harmonicznego. Krzywą przedstawiono na rycinie 3 . Obrazuje ona możliwość szybkiego osiągnięcia docelowego poziomu biegłości chirurga nabywającego kwalifikacji w wykorzystywaniu możliwości nowego narzędzia, jakim jest nóż harmoniczny. Analiza czasu trwania zabiegu operacyjnego nie wykazała natomiast istotnego jego skrócenia w kolejnych latach stosowania skalpela harmonicznego (ryc. 3).

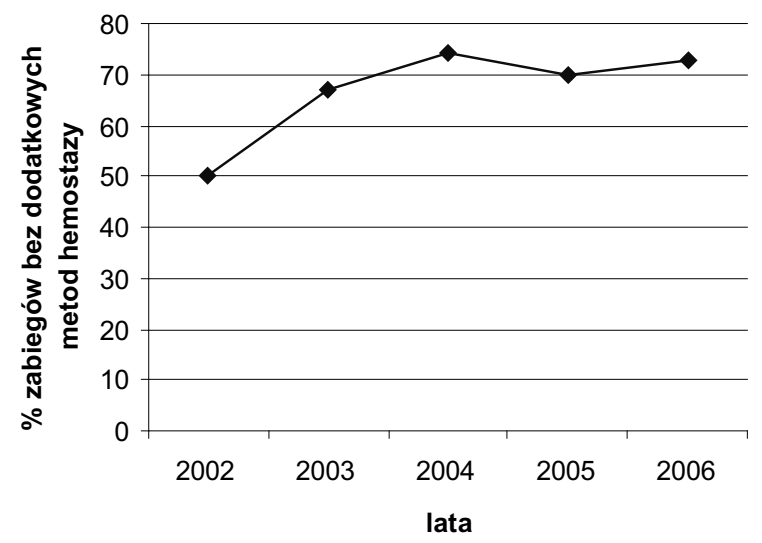

Ryc. 3. Krzywa uczenia się techniki tonsillektomii z zastosowaniem skalpela harmonicznego 


\section{DYSKUSJA}

\section{Hemostaza śródoperacyjna}

Analizując skuteczność skalpela harmonicznego jako narzędzia zapewniającego hemostazę śródoperacyjną większość autorów oparła się na porównaniu tej techniki z techniką klasyczną z zastosowaniem elektrokoagulacji [3, 4, 8-10, 17-22] lub bez niej [7, 11-13]. Wyniki niemal wszystkich prac zgodnie potwierdziły, że zastosowanie skalpela harmonicznego pozwala w sposób istotny ograniczyć krwawienie w trakcie zabiegu. W literaturze podkreślany jest wielokrotnie fakt, że nie u wszystkich chorych możliwe jest uzyskanie pełnej hemostazy wyłącznie z zastosowaniem skalpela harmonicznego [10, 16, 23]. W opublikowanych dotychczas pracach nie poruszano jednak kwestii związku skuteczności opanowania krwawienia przez skalpel harmoniczny z wiekiem operowanych pacjentów. Doświadczenie Katedry i Kliniki Otolaryngologii UJ CM wykazuje, że ryzyko krwawienia śródoperacyjnego, wymagającego zastosowania dodatkowych metod hemostazy, koreluje z wiekiem chorego. Doświadczenie Kliniki Otolaryngologii UJCM wykazuje, że u osób młodych i dzieci prawdopodobieństwo skutecznego opanowania krwawienia wyłącznie za pomocą skalpela harmonicznego jest istotnie wyższe niż u osób w starszym wieku przy takich samych wskazaniach do zabiegu operacyjnego, a w części przypadków możliwe jest przeprowadzenie zabiegu w sposób praktycznie bezkrwawy.

\section{Dolegliwości pooperacyjne}

Analizując nasilenie bólu pooperacyjnego u chorych operowanych za pomocą skalpela harmonicznego większość autorów stwierdziła mniejsze [3, 4, 7, 8, 14] lub zbliżone $[10,12,17,18]$ nasilenie dolegliwości, jak w grupie pacjentów operowanych techniką klasyczną (zarówno z zastosowaniem elektrokoagulacji, jak i bez niej). Jednak Leaper zanotował większe nasilenie bólu w grupie operowanej za pomocą skalpela harmonicznego w porównaniu z elektrokoagulacją [9]. Podobne wyniki uzyskał Oko, porównując pacjentów operowanych skalpelem harmonicznym i techniką klasyczną bez zastosowania elektrokoagulacji [13]. Akural zanotował wprawdzie niższy poziom bólu bezpośrednio po operacji u chorych operowanych nożem harmonicznym, ale w drugim tygodniu po operacji dolegliwości bólowe w tej grupie chorych okazywały się bardziej uciążliwe niż w grupie kontrolnej [11].

\section{Czas trwania zabiegu}

Wyniki badań dotyczących czasu trwania tonsillektomii z zastosowaniem skalpela harmonicznego w porównaniu z techniką klasyczną nie są zgodne. Rozbieżności opinii w tym zakresie sugerują, że czas trwania zabiegu przeprowadzanego za pomocą nowego narzędzia zależy głównie od umiejętności i indywidualnego doświadczenia operatora. Analiza materiału Katedry i Kliniki Otolaryngologii UJ CM również nie wykazała istotnej różnicy w tym zakresie pomiędzy techniką klasyczną a tonsillektomią z zastosowaniem skalpela harmonicznego.

\section{Powikłania pooperacyjne}

Szczególnie kontrowersje budzą wyniki cytowanych badań klinicznych w odniesieniu do ryzyka krwawień pooperacyjnych u pacjentów operowanych z zastosowaniem skalpela harmonicznego. Część autorów notuje większą [3, 22], część zaś mniejszą [8, 14, $18,21]$ liczbę krwotoków. W większości przypadków wyniki analiz nie są jednak istotne statystycznie (nawet w badaniach obejmujących kilkuset operowanych chorych). W przeglądzie systematycznym opublikowanym przez Neumanna w roku 2007 na postawie dostępnej literatury usiłowano w sposób obiektywny ocenić ryzyko krwawień pooperacyjnych po tonsillektomii z zastosowaniem skalpela harmonicznego [24]. Wyniki analizy dowiodły, że przeprowadzone dotychczas badania nie wyjaśniają w pełni tego zagadnienia. W materiale Katedry i Kliniki Otolaryngologii UJ CM stwierdzono większy odsetek krwawień pooperacyjnych w grupie chorych operowanych z użyciem skalpela harmonicznego niż w grupie kontrolnej. Niska sumaryczna liczba tych powikłań w obu grupach również w tym przypadku wyklucza jakiekolwiek wnioskowanie statystyczne. Odniesienie uzyskanych wyników do danych z literatury pozwala jednak przyjąć założenie, że ryzyko krwawienia pooperacyjnego nie wzrasta $\mathrm{w}$ sposób istotny w przypadku zastosowania noża harmonicznego w porównaniu z techniką klasyczną.

Krzywa uczenia się stosowania noża harmonicznego

Al-Bekaa [4] zwraca uwagę na stromy kształt krzywej uczenia się techniki tonsillektomii z zastosowaniem skalpela harmonicznego, co oznacza, że operator szybko jest w stanie opanować nową technikę operacyjną, a osiągnięcie biegłości nie wymaga długiego i żmudnego szkolenia. Własne doświadczenie potwierdza, że tonsillektomia z zastosowaniem skalpela harmonicznego jest stosunkowo łatwa do opanowania dla chirurga, który dotychczas posługiwał się klasyczną techniką usuwania migdałków podniebiennych.

\section{Ocena preparatu histopatologicznego}

Dodatkowym zagadnieniem, mającym znaczenie zwłaszcza w przypadku tonsillektomii przeprowadzanej w związku z podejrzeniem choroby nowotworowej, jest jakość preparatu histopatologicznego, jaki uzyskuje się usuwając migdałek za pomocą noża harmonicznego. Analiza przeprowadzona przez Metternicha 
wykazała, że koagulacja tkanek powodowana przez to narzędzie nie utrudnia patologowi oceny uzyskanego w ten sposób preparatu [23]. Na podstawie informacji ustnej uzyskanej od dyrektora Instytutu Patologii UJ CM w Krakowie prof. dr hab. med. J. Stachury martwica brzeżna tkanek ciętych przez nóż harmoniczny w ocenie mikroskopu świetlnego przy barwieniu preparatów hematoksyliną i eozyną jest daleko mniejsza niż w analogicznych tkankach przy zastosowaniu noża elektrycznego czy laserowego, jest zaś większa niż przy stosowaniu przez operatora noża stalowego w tym samym narządzie.

\section{WNIOSKI}

Na podstawie przeglądu literatury można wnioskować, że zastosowanie skalpela harmonicznego w tonsillektomii pozwala w większości przypadków znacznie zredukować krwawienie śródoperacyjne, a w części przypadków przeprowadzić zabieg w sposób niemal „bezkrwawy”. Teoretyczne założenie, że skalpel harmoniczny powinien powodować mniejsze dolegliwości bólowe niż elektrokoagulacja, nie znajduje natomiast jednoznacznego potwierdzenia. Zastosowanie nowego narzędzia nie powoduje również znacznego skrócenia czasu trwania tonsillektomii. Pytanie o ryzyko krwawień opóźnionych po tonsillektomii z zastosowniem skalpela harmonicznego pozostaje nadal otwarte.

Własne doświadczenie z zastosowaniem skalpela harmonicznego wykazuje, że technika ta może stanowić wartościową alternatywę dla klasycznych metod tonsillektomii. Jest to technika bezpieczna i efektywna, a przy tym stosunkowo łatwa do wyuczenia dla chirurgów wykonujących dotychczas tonsillektomię metodą klasyczną. Analiza przebiegu zabiegów przeprowadzonych w Klinice Otolaryngologii UJ CM pozwoliła zaobserwować nieopisywany dotychczas w literaturze związek skuteczności hemostazy śródoperacyjnej za pomocą skalpela harmonicznego z wiekiem operowanych chorych. Doświadczenie własne wskazuje, że w wybranych przypadkach nasilonego krwawienia śródoperacyjnego, zwłaszcza w starszych grupach wiekowych, należy liczyć się z koniecznością zastosowania dodatkowych metod hemostazy.

\section{PIŚMIENNICTWO}

1. Chmielik M, Zając B. Operacje migdałków podniebiennych i migdałka gardłowego u dzieci. Magazyn Otorynolaryngologiczny 2003; supl. 6: 9-16.
2. Andrzejewski J, Gryczyńska D, Krawczyński M, Zakrzewska A. Nowe tendencje w leczeniu operacyjnym migdałków u dzieci. Magazyn Otorynolaryngologiczny 2005; supl. 7: 27-30.

3. Collison PJ, Weiner R. Harmonic scalpel versus conventional tonsillectomy: a double-blind clinical trial. Ear Nose Throat J 2004; 83(10): 707-710.

4. Al-Bekaa S. Harmonic scalpel tonsillectomy vs diathermy tonsillectomy: a comparative study. Aust J Otolaryngol 2003; 6: 78-80.

5. Sood S, Corbridge R, Powles J, Bates G, Newbegin C. Effectiveness of the ultrasonic harmonic scalpel for tonsillectomy. Ear Nose Throat J. 2001; 80(8): 514-6, 518.

6. Fenton RS, Long J. Ultrasonic tonsillectomy. J Otolaryngol 2000; 29(6): 348-350.

7. Lachanas VA, Hajiioannou JK, Karatzias GT, Filios D, Koutsias S, Mourgelas C. Comparison of LigaSure vessel sealing system, harmonic scalpel, and cold knife tonsillectomy. Otolaryngol Head Neck Surg 2007; 137(3): 385-389.

8. Kamal SA, Basu S, Kapoor L, Kulandaivelu G, Talpalikar S, Papasthatis D. Harmonic scalpel tonsillectomy: a prospective study. Eur Arch Otorhinolaryngol 2006; 263(5): 449-454.

9. Leaper M, Mahadevan M, Vokes D, Sandow D, Anderson BJ, West T. A prospective randomised single blinded study comparing harmonic scalpel tonsillectomy with bipolar tonsillectomy. Int J Pediatr Otorhinolaryngol 2006; 70(8): 1389-1396.

10. Sheahan P, Miller I, Colreavy M, Sheahan JN, McShane D, Curran A. The ultrasonically activated scalpel versus bipolar diathermy for tonsillectomy: a prospective, randomized trial. Clin Otolaryngol Allied Sci 2004; 29(5): 530-544.

11. Akural EI, Koivunen PT, Teppo H, Alahuhta SM, Löppönen HJ. Post-tonsillectomy pain: a prospective, randomised and doubleblinded study to compare an ultrasonically activated scalpel technique with the blunt dissection technique. Anaesthesia 2001; 56(11): 1045-1050.

12. Sugiura N, Ochi K, Komatsuzaki Y, Nishino H, Ohashi T. Postoperative pain in tonsillectomy: comparison of ultrasonic tonsillectomy versus blunt dissection tonsillectomy. ORL J Otorhinolaryngol Relat Spec 2002; 64(5): 339-342.

13. Oko MO, Ganly I, Loughran S, Clement WA, Young D, Geddes NK. A prospective randomized single-blind trial comparing ultrasonic scalpel tonsillectomy with tonsillectomy by blunt dissection in a pediatric age group. Otolaryngol Head Neck Surg 2005; 133(4): 579-584.

14. Willging JP, Wiatrak BJ. Harmonic scalpel tonsillectomy in children: a randomized prospective study. Otolaryngol Head Neck Surg 2003;128(3): 318-325.

15. Wiatrak BJ, Willging JP. Harmonic scalpel for tonsillectomy. Laryngoscope 2002;112(8 Pt 2 Suppl 100): 14-16.

16. Morgenstein SA, Jacobs HK, Brusca PA, Consiglio AR, Donzelli J, Jakubiec JA, i wsp. A comparison of tonsillectomy with the harmonic scalpel versus electrocautery. Otolaryngol Head Neck Surg 2002; 127(4): 333-338. 
17. Parsons SP, Cordes SR, Comer B. Comparison of posttonsillectomy pain using the ultrasonic scalpel, coblator, and electrocautery. Otolaryngol Head Neck Surg 2006; 134(1): 106-1013.

18. Potts KL, Augenstein A, Goldman JL. A parallel group analysis of tonsillectomy using the harmonic scalpel vs electrocautery. Arch Otolaryngol Head Neck Surg 2005; 131(1): 49-51.

19. Shinhar S, Scotch BM, Belenky W, Madgy D, Haupert M. Harmonic scalpel tonsillectomy versus hot electrocautery and cold dissection: an objective comparison. Ear Nose Throat J. 2004; 83(10): 712-715.

20. Haegner U, Handrock M, Schade H. "Ultraschalltonsillektomie" im Vergleich zur konventionellen Tonsillektomie. HNO 2002; 50(9): 836-843.

21. Walker R, Syed ZA. Harmonic scalpel tonsillectomy versus electrocautery tonsillectomy. A comparative pilot study. Otolaryngol Head Neck Surg 2001; 125: 449-455.

22. Schrey A, Pulkkinen J, Fremling C, Kinnunen I. Ultrasonically activated scalpel compared with electrocautery in tonsillectomy ORL J Otorhinolaryngol Relat Spec. 2004; 66(3): 136-140.
23. Metternich FU, Sagowski C, Wenzel S. Tonsillectomy with the ultrasound activated scalpel. Initial results of technique with Ultracision Harmonic Scalpel. HNO 2001; 49(6): 465-470.

24. Neumann C, Street I, Lowe D, Sudhoff H. Harmonic scalpel tonsillectomy: a systematic review of evidence for postoperative hemorrhage. Otolaryngol Head Neck Surg 2007; 137(3): 378384 .

\author{
Adres autora: \\ Marian Kurzyński \\ ul. Śniadeckich 2 \\ 31-501 Kraków
}

Pracę nadesłano: 10.04.2008 $\mathrm{r}$

Zaakceptowano do druku: 20.06.2008 r 